\title{
GENOCIDE DAN WAR CRIME: SEBUAH PERBANDINGAN DARI SUDUT PANDANG GRAVE BREACHES (PELANGGARAN HAK ASASI MANUSIA BERAT)
}

\author{
Oleh : \\ Indah Sari, SH, M.Si \\ Dosen Tetap Fakultas Hukum Universitas Suryadarma dan \\ aktif di LKBH Fakultas Hukum Universitas Suryadarma serta anggota Asosiasi Dosen Seluruh Indonesia (ADI) \\ Email : (indah.alrif.@gmail.com)
}

\begin{abstract}
Abstrak:
This writing propose to explain some criterions of grave breaches, which is constituted of genocide, war crime, aggression and crime against humanity. Genocide means any of the following acts committed with intent to destroy, in whole or in part, a national, ethnical, racial or group. War Crimes: Namely, violations of the laws or customs of war. Such violations shall include, but not be limited to, murder, illtreatment or deportation to slave labour or for any other purpose of civilian populations of or in occupied territority, murder or ill-treatment of prisoners of war or persons on the seas, killing of hostages, plunder of public of private property, wanton destruction of cities, town or villages, or devastation not justified by military necessity. Finally, this writing focused about some differences between Genocide and War Crime
\end{abstract}

Keywords: Human Rights, Grave Breaches, Genocide, War Crime.

\section{PENDAHULUAN}

Istilah Grave Breaches mungkin di dengar sangat asing bagi masyarakat umum. Sebenarnya Graves Breaches bukan sesuatu yang asing bagi kita semua, dalam kenyataannya banyak kita temui tindakan-tindakan yang mengandung unsur-unsur Graves Breaches. Apa itu Grave Breaches? Jika diartikan ke dalam bahasa Indonesia Grave Breaches adalah pelaggaran Hak Asasi Manusia (HAM) berat. Pada pasal 50 Konvensi Genewa 1949 dimana dijelaskan bahwa Grave Breaches yaitu pelanggaran pelanggaran yang meliputi perbuatanperbuatan berikut, apabila dilakukan terhadap orang atau milik yang dilindungi oleh Konvensi : pembunuhan disengaja, penganiayaan atau perlakuan yang tidak berperikemanusiaan, termasuk percobaan - percobaan biologis, menyebabkan dengan sengaja penderitaan besar atau luka berat atas badan atau kesehatan, serta penghancuran yang luas dan tindakan 
perampasan atas harta benda yang tidak dibenarkan oleh kepentingan militer.

Internasional Criminal Court (ICC) telah mengklasifikasikan empat bentuk pelanggaran HAM berat yaitu: Genosida, Kejahatan Terhadap Kemanusiaan, Kejahatan Perang dan Kejahatan Agresi. Dan di pasal 5 Statuta Roma tahun 1998 menyebutkan bahwa yurisdiksi dari Internasional Criminal Court (ICC) adalah: $^{2}$

a. Kejahatan Genosida (the crime of genocide)

b. Kejahatan Kemanusiaan (crimes against humanity)

c. Kejahatan Perang (war crime)

d. Kejahatan Agresi (the crime of aggression)

Dalam konteks Hukum Nasional, kita dapat menjumpai pengertian Grave Breaches di Undang-Undang No. 26 Tahun 2000 tentang Pengadilan HAM pasal 7 dimana dinyatakan bahwa: pelanggaran Hak Asasi Manusia Berat meliputi: ${ }^{3}$

a. Kejahatan Genosida

b. Kejahatan Kemanusiaan

Dari uraian diatas kita dapat menyimpulkan bahwa Grave Breaches sudah tegas-tegas telah diatur dalam Hukum Nasional maupun dalam Hukum Internasional. Tetapi di dalam tulisan ini penulis hanya mengkaji dua tindakan yang termasuk dalam Graves Breaches yaitu Genosida (Genocide) dan kejahatan perang (War Crime). Mengapa penulis hanya mengkaji

${ }^{1}$ Pasal 50 Konvensi Jenewa 1949.

${ }^{2}$ Lihat Pasal 2 Statuta Roma 1998.

${ }^{3}$ Baca Pasal 7 Undang-Undang No. 26 Tahun 2000 tentang Pengadilan HAM lebih dalam lagi terhadap Genocide dan War Crime? Kerena menurut penulis ada persamaan-persamaan dan perbedaan-perbedaan yang signifikan antara Genocide dan War Crime sehingga akhirnya penulis mengangkat dua permasalahan dalam tulisan ini yaitu: pertama, bagaimana kriteria daari Grave Breaches (pelanggaran Hak Asasi Manusia Berat)? kedua, apa persamaan dan perbedaan dari Genocide dan War Crime ditinjau dari sudut pandang Graves Breaches?

Adapun tujuan dari penulisan ini adalah:

1. Untuk mengkaji dan menganalisis kriteria dari Grave Breaches (Pelanggaran Hak Asasi Berat) Dimana penulis melihat perbuatan-perbuatan apa yang termasuk ke dalam Grave Breaches dan dimanakah perbuatanperbuatan itu di atur. Disamping itu juga melihat unsur-unsur dari Grave Breaches.

2. Untuk mengkaji dan mencari dimanakah perbedaan antara Genocide dan War Crime yang merupakan bagian dari Grave Breaches (Pelanggaran Hak Asasi Manusia Berat) dan kemudian penulis juga akan menambahkan sedikit analisis kaitan antara Genocide (Genosida) dengan Pengadilan HAM berat begitu juga dengan War Crime (kejahatan perang)

Kemudian untuk menganalisis permasalahan dalam tulisan ini penulis mencoba pertama, mengkaji pengertian HAM dari berbagai istilah. Kemudian melihat pengaturaan HAM 
dari peraturan yang bertaraf internasional dan nasional. Setelah mendapatkan pengertian HAM penulis mencoba mengkaitan antara HAM dengan Grave Breaches (Pelanggaran Hak Asasi Berat).

Berbicara Grave Breaches tidak bisa terlepas dari pembicaraan HAM. Baru kemudian penulis masuk ke dalam pengertian Grave Breaches serta dasar hukumnya apa. Terakhir baru masuk kepada perbuatan-perbuatan apa saja yang masuk ke dalam Grave Breaches. Kedua, penulis mencoba untuk memaparkan serta menjelaskan apa itu Genosida serta apa ukuran dari sebuah perbuatan baru dapat dikatakan sebuah perbuatan Genosida. Dan juga akan menguraikan beberapa aturan yang mengatur tentang Genosida. Untuk mempertajam analisis penulis, penulis memaparkan beberapa kasus Genosida terbesar yang pernah terjadi di muka bumi. Ketiga, dimana sesuai dengan tujuan penulisan ini yang mencoba mencari dimana perbedaan dan persamaan antara Genocide dan War Crime, maka pembahasan selanjutnya adalah membahas tentang War Crime.

Penulis mencoba melihat kriteria dan perbuatan-perbuatan dari War Crime, peraturan-peraturan internasional maupun nasional apa saja yang mengatur War Crime. Keempat, pada point keempat ini penulis menganalisis tentang Pengadilan HAM Berat karena pelaku Genocide dan War Crime biasanya diadili di Pengadilan HAM berat. Disini penulis melihat apa yang dimaksud dengan Pengadilan HAM berat, dasar hukumnya apa, berkedudukan dimana pengadilan HAM tersebut, mekanisme pengadilan HAM bagaimana. Kemudian baru penulis melihat yurisdiksi Pengadilan HAM Berat. Kelima, kesimpulan dari tulisan penulis, tentu dalam kesimpulan penulis mencoba menjawab dua permasalahan yang penulis angkat dalam tulisan ini.

Berdasarkan pada uraian diatas akhirnya penulis sangat tertarik untuk mengkaji dan menganalisis lebih dalam tentang Grave Breaches, karena mengenai Grave Breaches ini banyak kalangan yang tidak mengatahui apa itu Grave Breaches serta perbuatanperbuatan apa yang termasuk Grave Breaches. Genocide dan War Crime yang merupakan bagian dari Grave Breaches akan penulis kaji lebih dalam karena penulis meihat ada persamaan dan perbedaan signifikan antara Genocide dan War Crime. Harapan penulis semoga tulisan ini bermanfaat bagi akademisi, mahasiswa, penggiat HAM, penegak hukum, pemerintah serta masyarakat pada umumnya.

\section{PERMASALAHAN}

1. Bagaimanakah kriteria dari Grave Breaches (Pelanggaran Hak Asasi Manusia Berat)?

2. Apa persamaan dan perbedaan dari Genocide dan War Crime ditinjau dari sudut pandang Grave Breaches (Pelanggaran Hak Asasi Manusia Berat)? 


\section{PEMBAHASAN}

A. GRAVE BREACHES (PELANGGARAN HAK ASASI MANUSIA BERAT)

Sebelum membahas mengenai Grave Breaches alangkah baiknya kita harus memahami terlebih dahulu kajian mengenai Hak Asasi Manusia, karena antara pengertian Grave Breaches tidak bisa dipisahkan dari makna yang terkandung dalam pengertian akan Hak Asasi Manusia.

Ditinjau dari berbagai istilah yang ditemukan dalam literatur, hak asasi manusia merupakan terjemahan dari "droits de I'homme" dalam bahasa Perancis yang berarti manusia atau dalam bahasa Inggrisnya "Human Rights" dan dalam bahasa Belanda disebut "Mensenrechten".

Dalam kepustakaan lain digunakan istlah-istilah dasar yang merupakan terjemahan "basic rights" dalam bahasa Inggris dan "grondrechten" dalam bahasa Belanda. Sebagian orang menyebutnya dengan hak-hak fundamental sebagai terjemahan dari "fundamental rights" dalam bahasa Inggris dan "fundamentele rechten" dalam bahasa Belanda.

Istilah lain tentang Hak Asasi Manusia sebagaimana dikemukan oleh Hadjon (1987:38), ada dalam kepustakaan bahasa Inggris yang mempergunakan istilah "Natural right" dan dalam bahasa Belanda digunakan istilah "rechten van den mens" sedang dalam kepustakaan yang berbahasa Indonesia terdapat istilah-istilah seperti hakhak asasi manusia, hak-hak kodrati dan hak-hak dasar. Pada sisi lain kepustakaan hukum selain menggunakan hak dasar sebagai terjemahan dari "grondrachtan", "grundrechte", "fundamental right", "droits fundamentaux" juga menggunakan istilah hak-hak asasi manusia sebagai terjemahan dari "mensenrechten", "menchenrechte", "human rights", dan "droits de I'homme"s $^{\text {' }}$

Sedangkan pengertian Hak Asasi Manusia menurut Deklarasi Universal Hak Asasi Manusia yang dirumuskan oleh PBB pada tahun 1948 yang merupakan dokumen tertulis Hak Asasi Manusia pertama yang dihasilkan oleh negara-negara dan bangsabangasa yang mewakili latar belakabg budaya, kepercayaan, ideologi dan politik merumuskan bahwa Hak Asasi Manusia adalah Hak untuk kebebasan dan persamaan dalam derajat yang diperoleh sejak lahir dan tidak dapat dicabut dari seseorang. ${ }^{5}$

Berdasarkan Deklarasi Universal Hak Asasi Manusia PBB tahun 1948 dan Indonesia sebagai anggota Perserikatan BangsaBangsa (PBB) mengemban tanggungjawab moral dan hukum untuk menjunjung tinggi tentang Hak Asasi Manusia yang ditetapkan oleh PBB, serta

\footnotetext{
${ }^{4}$ Bahder Johan Nasution, Negara Hukum Dan Hak Asasi Manusia, Mandar Maju, Bandung, 2012, hal.129-130.

${ }^{5}$ Lihat lebih lanjut Deklarasi Universal Hak Asasi Manusia yang dirumuskan PBB pada tahun 1948
} 
berbagai instrumen internasional lainnya mengenai hak asasi manusia yang telah diterima oleh Negara Republik Indonesia maka di Hukum Nasionalnya Bangsa Indonesia menuangkan ketentuan tentang Hak Asasi Manusia ini dalam Undang-Undang Hak Asasi Manusia Nomor 39 Tahun 1999.

Dimana di dalam pasal 1 dijelaskan bahwa " Hak Asasi Manusia adalah seperangkat hak yang melekat pada hakikat dan keberadaan manusia sebagai makhluk Tuhan Yang Maha Esa dan merupakan anugerah-Nya yang wajib dihormati, dijunjung tinggi dan dilindungi oleh Negara, Hukum, Pemerintahan dan setiap orang demi kehormatan dan perlindungan harkat dan martabat manusia. ${ }^{6}$ Pengertian hak asasi manusia tersebut sekurang-kurangnya mengandung tiga hak elemen yang tidak boleh dicabut dari seseorang sebagai individu, yakni hak untuk hidup, hak untuk tidak dianiaya, dan adanya kebebasan.

Disamping itu juga ada hak ekonomi, sosial dan budaya yang dimilki oleh setiap orang sebagai anggota masyarakat dan tidak dapat dikesampingkan bagi martabat manusia dan kebebasan dalam mengembangkan kepribadiannya. Dari pengertian hak asasi manusia juga muncul pengakuan bahwa setiap orang berhak atas ketertiban sosial dan internasional sehingga dalam

${ }^{6}$ Pasal1 Undang-Undang Nomor 39 tahun 1999 tentang Hak Asasi Manusia (HAM) melaksankan hak dan kebebasannya, setiap orang tunduk pada pembatasan yang ditetapkan oleh hukum. ${ }^{7}$

Asas-asas dasar mengenai pengakuan Hak Asasi Manusia ini tertuang pada pasal 2 sampai dengan pasal 8 UU Nomor 39 tahun1999 yang mana dinyatakan sebagai berikut: 8

Pasal 2: Negara Republik Indonesia mengaku dan menjunjung tinggi hak asasi manusia dan kebebasan dasar manusia sebagai hak yang secara kodrati melekat pada dan tidak terpisahkan dari manusia, yang harus dilindungi, dihormati, dan ditegakan demi peningkatan martabat kemanusiaan, kesejahteraan, kebahagiaan, dan kecerdasan serta keadilan.

Pasal 3:

1. Setiap orang dilahirkan bebas dengan harkat dan martabat manusia yang sama dan sederajat serta dikaruniai akal dan hati nurani untuk hidup bermasyarakat, berbangsa dan bernegara dalam semangat persaudaraan.

2. Setiap orang berhak atas pengakuan, jaminan, perlindungan dan perlakuan hukum yang adil serta mendapat kepastian hukum dan perlakuan yang sama di depan hukum.

\footnotetext{
${ }^{7}$ Bahder Johan Nasution, Op.Cit, hal 130-131.

${ }^{8}$ Pasal 2, 3, 4, 5, 6, 7 dan 8 Undang-Undang Nomor 39 tahun 1999 tentang Hak Asasi Manusia (HAM)
} 
3. Setiap orang berhak atas perlindungan hak asasi manusia dan kebebasan dasar manusia tanpa diskriminasi.

Pasal 4:

Hak untuk hidup, hak untuk tidak disiksa, hak kebebasan pribadi, pikiran dan hati nurani, hak beragama, hak untuk tidak diperbudak, hak untuk diakui secara pribadi dan persamaan di depan hukum, dan hak untuk tidak dituntut atas dasar hukum yang berlaku surut adalah hak asasi manusia yang tidak dapat dikurangi dalam keadaan apapun dan oleh siapapun.

Pasal 5:

1. Setiap orang diakui sebagai manusia pribadi yang berhak menuntut dan memperoleh perlakuan serta perlindungan yang sama sesuai dengan martabat kemanusiannya di depan hukum.

2. Setiap orang berhak mendapat bantuan dan perlindungan yang adil dari pengadilan yang objektif dan tidak berpihak

3. Setiap orang yang termasuk kelompok masyarakat yang rentan berhak memperoleh perlakuan dan perlindungan lebih berkenaan dengan kekhususannya.

Pasal 6:

1. Dalam rangka penegakan hak asasi manusia, perbedaan dan kebutuhan dalam masyarakat hukum adat harus diperhatikan dan dilindungi oleh hukum, masyarakat dan pemerintahan.

2. Identitas budaya masyarakat hukum adat, termasuk hak atas tanah ulayat dilindungi selaras dengan perkembangan zaman.

Pasal 7:

1. Setiap orang berhak kuntuk menggunakan semua upaya hukum nasional dan forum internasional atas semua pelanggaran hak asasi manusia yang dijamin oleh hukum Indonesia dan hukum Internasional mengenai hak asasi manusia yang telah diterima oleh Negara Republik Indonesia.

2. Ketentuan hukum Internasional yang telah diterima Negara Republik Indonesia yang menyangkut hak asasi manusia menjadi hukum nasional.

Pasal 8:

Perlindungan, pemajuan, penegakan dan pemenuhan hak asasi manusia terutama menjadi tanggung jawab pemerintahan.

Dari uraian diatas kita dapat melihat apa makna dari Hak asasi manusia tersebut, apa ruang lingkupnya, apa-apa saja asasasas dan dasar-dasar dari hak asasi manusia. Serta bagaimana peran hukum internasional maupun nasional dalam penegakan Hak Asasi Manusia (HAM). Selanjutnya kita akan coba membahas apa-apa saja 
yang termasuk pelanggaran HAM Berat (Grave Breaches). Bagaimana kita melihat Grave Breaches dari sudut pandang HAM dalam konteks Nasional maupun Internasional.

Perkembangan berbagai bentuk kejahatan yang terjadi dalam masyarakat internasional yang berakibat terjadinya korbankorban yang tidak manusiawi, sehingga tergolong kejahatan pelanggaran Hak Asasi Manusia Berat (Grave Breaches) yang meliputi: kejahatan perang, genosida, kejahatan kemanusiaan, dan agressi. Dari beberapa bentuk kejahatan yang tergolong pelanggaran HAM berat tersebut menjadi kewenagan mutlak Mahkamah Pidana Internasional yang mengadili para pelakunya. Hal ini bersadarkan pasal 5 Statuta Roma tahun 1998 yang menyebutkan bahwa yurisdiksi dari International Criminal Court (ICC) adalah sebagai berikut: ${ }^{9}$

1. Kejahatan Genosida (the crime of genocide)

2. Kejahatan Kemanusiaan (crimes againts humanity)

3. Kejahatan Perang (war crime)

4. Kejahatan Agresi (the crime of aggression)

Selanjutnya yang dimaksud dengan pelanggaran-pelanggaran berat (grave breaches) adalah tindakan - tindakan yang dikategorikan sebagai pelanggaran - pelanggaran berat

${ }^{9}$ Anis Widyawati, Hukum Pidana Internasional, Sinar Grafika, Jakarta, 2014,. hal 57 dalam Konvensi Jenewa 1949 dan Protokol Tambahan 1977 yang berlaku dalam sengketa/konflik bersenjata Internasional. ${ }^{10}$

Adapun pelanggaran-pelanggaran berat (grave breaches) yang dimaksud lebih diuraikan lagi di pasal 50 Konvensi Genewa 1949 dimana dijelaskan bahwa grave breaches yaitu pelanggaranpelanggaran yang meliputi perbuatan - perbuatan berikut, apabila dilakukan terhadap orang atau milik yang dilindungi oleh Konvensi: pembunuhan disengaja, penganiayaan atau perlakuan yang tidak berperikemanusiaan, termasuk percobaan-percobaan biologis, menyebabkan dengan sengaja penderitaan besar atau luka berat atas badan atau kesehatan, serta penghancuran yang luas dan tindakan perampasan atas harta benda yang tidak dibenarkan oleh kepentingan militer $^{11}$

Selaian dalam pasal 50 Konvensi Jenewa 1949 Grave Breaches juga diatur di pasal 85 Protokol Tambahan 1977 bahwa dari pasal tersebut dalam ayat 1 dijelaskan:

"Ketentuan-ketentuan Konvensi tentang penindakan terhadap pelanggaran dan pelanggaran berat yang ditambah dengan bagian ini, akan berlaku terhadap penindakan pelanggaran dan pelanggaran-pelanggaran berat Protokol ini"

${ }^{10}$ Lihat Konvensi Jenewa 1949 dan Protokol

Tambahan 1977.

${ }^{11}$ Pasal 50 Konvensi Jenewa 1949 
Dijelaskan pula dalam ayat 5 yang menyatakan:

"Tanpa mengurangi penerapan Konvensi dan Protokol ini, pelanggaran - pelanggaran berat atas piagam-piagam tersebut harus disebut kejahatan perang"

Berdasarkan uraian pasal tersebut dapat disimpulkan pelanggaranpelanggaran berat/grave breaches yang dicantumkan baik dalam Konvensi Jenewa maupun Protokol Tambahan 1977 dapat dianggap sebagai kejahatan perang. ${ }^{12}$

Pelanggaran - pelanggaran terhadap Konvensi Jenewa 1949 yaitu masing-masing dari perbuatan berikut ini terhadap orang-orang atau hak milik yang dilindungi berdasarkan ketentuan Konvensi Jenewa yang bersangkutan: ${ }^{13}$

1. Pembunuhan yang dilakukan dengan sadar

2. Penyiksaan atau perlakuan tidak manusiawi, termasuk percobaan biologis

3. Secara sadar menyebabkan penderitaan berat, atau luka serius terhadap badan atau kesehatan

4. Perusakan meluas dan perampasan hak milik, yang tidak dibenarkan oleh kebutuhan militer dan dilakukan secara tidak sah dan tanpa alasan.

5. Memaksa seorang tawanan perang atau orang lain yang dilindungi untuk berdinas

${ }^{12}$ Anis Widyawati, Op.Cit. hal 75

${ }^{13} \mathrm{Ibid}$, hal 75-76 dalam pasukan dari suatu kekuatan yang bermusuhan.

6. Secara sadar merampas hakhak seorang tawanan perang atau orang lain yang dilindungi atas pengadilan yang jujur dan adil.

7. Deportasi tidak sah atau pemindahan atau penahanan tidak sah

8. Menahan sandera.

\section{B. GENOCIDE (GENOSIDA)}

Kejahatan genosida merupakan bentuk kejahatan yang mempunyai tujuan untuk pemusnahan etnis (ethnical cleansing) dengan melakukan penyerangan kaum lain. Menurut Majelis Umum Perserikatan Bangsa-Bangsa juga memberikan pernyataan mengenai kejahatan genosida bahwa kejahatan tersebut mencakup kejahatan terhadap kelompok-kelompok politik (political groups) karena dalam pandangan oleh komite PBB adalah kelompok-kelompok yang tidak dengan mudah diidentifikasi (non-readly identifiable) dalam hal kelompok politik yang akan menyebabkan gangguan internasional dalam permasalahan politik dalam negeri suatu negara (Bassiouni 1996:28).

Pengertian lain juga diberikan Raphel Lemkin seorang ahli hukum dari Polandia pada tahun 1944 dalam bukunya Axis Rule in Occupied Europe (dalam Wikipedia) menyatakan bahwa genosida adalah sebuah 
pembantaian besar-besaran secara sistematis terhadap suatu suku bangsa atau kelompok dengan maksud memusnahkan bangsa tersebut. Pengertian genosida secara yuridis yaitu sebagai tindakan dengan maksud menghancurkan dan memusnahkan seluruh atau sebagian kelompok bangsa, ras, etnis dan agama.

Definisi tersebut merupakan penjelasan yang tertuang di dalam Convention on Prevention and Punishment of the Crime of Genocida (Konvensi tentang pencegahan dan penghukuman terhadap kejahatan genosida) pada tahun 1948. Konvensi Genosida tersebut dijadikan pedoman untuk melakukan pengadopsian definisi genosida Statuta Roma tahun 1998 dan Undang-Undang nomor 26 tahun 2000 tentang Pengadilan Hak Asasi Manusia. ${ }^{14}$

Istilah genocide (Inggris) atau genosida (Indonesia) terdiri dari dua kata yakni geno dan side. Geno atau genos berasal dari bahasa Yunani Kuno yang berarti ras, bangsa atau etnis. Sedangkan cide, caedere, atau cidium berasal dari bahasa Latin yang berarti membunuh. Selanjutnya genosida ini didefinisikan dalam Convention on the Prevention and Punishmentof the Crime og Genocide yang diterima oleh Resolusi Majelis Umum PBB 260A (III), 9 Desember 1948. Dalam pasal 1 konvensi tersebut dinyatakan bahwa genosida yang dilakukan pada waktu damai atau pada

${ }^{14}$ Anis Widyawati, Op.Cit hal. 58-59. waktu perang adalah kejahatan menurut hukum internasional (......genocide, whether commited in time of peace or in time of war, is a crime under internastional law......)

Secara lengkap dalam pasal $2:{ }^{15}$

In the present convention genocide means any of the following act committed with intent to destroy, in whole or in part, a national, etnical, racial or religius groups, as such:

a. Killing members of the groups

b. Causing serious bodily or mental harm to members of the group.

c. Deliberately inflicting on the group conditions of life calculated to bring about its physical destruction in or in part.

d. Impossing measures intended to prevent births within the group

e. Forcibly transferring children of the group to anather group.

Dalam Konvensi ini genosida diartikan sebagai perbuatanperbuatan berikut, yang dilakukan dengan tujuan merusak begitu saja, keseluruhan atau sebagian, suatu kelompok bangsa, etnis, rasial, atau agama seperti: ${ }^{16}$

a. Membunuh para anggota kelompok

b. Menyebabkan luka-luka pada tubuh atau mental para anggota kelompok

c. Dengan sengaja menimbulkan pada kelompok itu kondisi hidup yang menyebabkan

\footnotetext{
${ }^{15}$ Untuk memahami Gonosida baca lebih lanjut Eddy O.S Hiariej, Hukum Pidana Internasional, Penerbit Erlangga, Jakarta, 2009, hal 58-60.

${ }^{16} \mathrm{Ibid}$, hal. 60
} 
kerusakkan fisiknya secara keseluruhn atau sebagian.

d. Mengenakan upaya-upaya yang dimaksud untuk mencegah kelahiran di dalam kelompok itu.

e. Dengan paksa mengalihkan anak-anak suatu kelompok ke kelompok lainnya.

Sementara Pasal 3 Konvensi menyebutkan bahwa perbauatanperbuatan yang dapat dihukum adalah genosida, persekongkolan untuk melakukan genosida (conspiracy to commit genocide), hasutan langsung dan di depan umum untuk melakukan genosida (direct and public incitement to commit genocide), mencoba melakukan genosida (attempt to commit genocide) dan keterlibatan dalam genosida (complicity in genocide). Dengan kata lain permufakatan jahat, percobaan dan penyertaan melakukan genosida, dihukum sebagaimaana melakukan genosida. ${ }^{17}$

Kategori pelanggaran HAM berat yang dimaksud adalah pelanggaran yang merupakan kejahatan genosida dan kejahatan terhadap kemanusiaan sebagaimana yang diatur dalam pasal 6 dan pasal 7 Rome Statute of The International Criminal Court. Kejahatan genosida ini merupakan kejahatan yang dilakukan dengan maksud untuk menghancurkan atau memusnahkan seluruh atau sebagian kelompok bangsa, ras, kelompok etnis kelompok agama dengan cara: ${ }^{18}$

1. Membunuh anggota kelompok, pengettian anggota kelompok disini adalah seorang atau lebih angggota kelompok.

2. Mengakibatkan penderitaan fisik atau mental yang berat terhadap anggota-anggota kelompok.

3. Menciptakan kondisi kehidupan kelompok yang akan mengakibatkan kemusnahan secara fisik baik seluruh atau sebagiannya.

4. Memaksakan tindakantindakan yang bertujuan mencegah kelahiran di dalam kelompok, atau

5. Memindahkan secara paksa anak-anak dari kelompok tertentu ke kelompok lain.

Di bawah ini akan dijelaskan mengenai peristiwa kasus genosida yang pernah terjadi di masyarakat internasional, antara lain: ${ }^{19}$

1. Kejahatan Genosida yang dilakukan oleh kaum Nazi (Jerman) atas pemimpin Hitler dalam membantai orang-orang Yahudi, orang Gipsi (kaum Sinti dan Roma) dan suku bangsa Slavia yang berlangsung selama Perang Dunia II.

2. Kejahatan genosida yang terjadi kepada bangsa Armenia yang dilakukan oleh kelompok

\footnotetext{
${ }^{18}$ Lihat lebih lanjut pasal 6 dan pasal 7 Statuta Roma 1998

${ }^{19}$ Anis Widyawati, Op. Cit hal. 67
} 
Genocide Dan War Crime: Sebuah Perbandingan Dari Sudut Pandang Grave Breaches (Pelanggaran Hak Asasi Manusia Berat)

bangsa Turki yang

berlangsung diakhir terjadinya

Perang Dunia II.

3. Kejahatan genosida yang dilakukan oleh rezim Saddam Husain kepada bangsa Kurdi pada tahun 1980-an

4. Kejahatan Genosida yang terjadi di Negara Guatemala oleh pemimpinnya yang terkenal diktator Efrain Rios Montt, dengan kekuasaanya melakukan pembunuhan sekitar 75.000 suku Indian Maya yang terjadi pada tahun 1982 sampai dengan 1983.

5. Kejahatan Genosida yang terjadi di Rwanda, pemusnahan yang terjadi kepada suku Hutu dan Tutsi pada tahun 1994.

6. Kejahatan genosida yang terjadi di Yugoslavia oleh bangsa Serbia pada tahun 1991-1996 yang melakukan pembantaian suku Bosnia dan Kroasia

7. Kejahatan genosida yang dilakukan oleh pemerintahan Myanmar kepada kaum Rohingya (muslim minoritas) dengan cara melakukan pengusiran terhadap kaum Rohingya. Sehingga kaum Rohingya mencari perlindungan suaka politik ke beberapa negara di Asia Tenggara. ${ }^{20}$

\section{WAR CRIME (KEJAHATAN PERANG)}

Perang merupakan suatu keadaan yang tidak pernah diharapakan

${ }^{20}$ Baca lebih lanjaut TEMPO 8-14 Juni 2015 bahkan dibenci oleh setiap manusia. Keadaan perang yang dimaksud adalah perang yang membawa kesengsaraan bagi semua pihak ataupun memakan banyak korban luka dan mati akibat perang tersebut. Keadaan itulah yang mengancam keselamatan kehidupan manusia dan juga dapat diperlakukan secara tidak manusiawi oleh pihak musuh. ${ }^{21}$

Secara sederhana perang adalah tindakan kekerasan yang dilakukan untuk menaklukkan negara lawan untuk membebankan syarat-syarat penyelesaian secara paksa. Perang oleh Quincy Wright diartikan dalam dua bentuk, legal sense dan material sense. War in the legal sense as a condition or period of time in which special rules permitting and regulating violence by which disputes between governments are settled, and war in material sense as an act or a series of acts of violence by one government against another, or a dispute between goverments carried on by violence. ${ }^{22}$

Sedangkan pemahaman mengenai kejahatan perang (war crime) yang lain adalah suatu tindakan pelanggaran, dalam cakupan hukum internasional terhadap hukum perang oleh satu atau beberapa orang, baik militer maupun sipil. Pelaku kejahatan perang disebut sebagai penjahat

${ }^{21}$ Anis Widyawati, Op. Cit , hal 72

${ }^{22}$ Lihat lebih lanjut, Tholib Effendi, Hukum Pidana Internasional, Pustaka Yustisia, Yogyakarta, 2014 , hal. 77-78. Dan lihat juga Quincy Wright, $A$ Study of War Volume I, The University of Chicago Press, Chicago, 1941, p.8. 
perang (Turangan, 2011:5).

Kejahatan meliputi semua pelanggaran yang telah ditentukan di dalam hukum perang dan juga mencakup kegagalan untuk tunduk pada norma dan aturan-aturan pertempuran. Sebagai contoh, melakukan penyerangan pada pihak yang telah mengibarkan bendera putih yang merupakan tanda sebagai tanda perdamaian ${ }^{23}$ Disamping itu juga definisi kejahatan perang juga dapat diartikan tindakan-tindakan yang melanggar hukum dan kebiasaan yang berlaku di dalam peperangan.

Meski demikian, tidak dapat dikatakan bahwa setiap pelanggaran terhadap hukum dan kebiasaan perang serta merta merupakan kejahatan perang. Istilah kejahatan perang lebih menunjuk pada pelanggaran terhadap hukum dan kebiasaan dalam perang, jus in bello, pelanggaran terhadap jus ad bellum merupakan kualifikasi tersendiri dalam tindak pidana internasional, yaitu kejahatan terhadap perdamaian, dan/atau agresi. $^{24}$

Menjadi sebuah pertanyaan, dimana sajakah kejahatan perang ini diatur? Mengenai kejahatan perang kita dapat merujuk pada ketentuan:

\section{Menurut Peraturan \\ Perundang - undangan Nederlands-Indie ${ }^{25}$}

Menurut Pasal 1 Stb 1946 No.44 yang dimaksud dengan kejahatan perang adalah perbuatan-perbuatan yang melanggar undang-undang atau adat kebiasaan perang, dilakukan dalam masa perang oleh bawahan sebuah negara musuh atau oleh orang-orang asing antek-antek musuh, seperti:

1) Pembunuhan dan pembunuhan massal

2) Teror yang sistematis.

3) Pembunuhan tawanan gijzelaar (orang yang ditahan sebagai jaminan /sandera)

4) Penganiayaan penduduk sipil

5) Dengan sengaja membuat penduduk lapar

6) Penculikan gadis-gadis atau wanita-wanita untuk dipaksa menjadi pelacur atau pemaksaan untuk dijadikan pelacur

7) Pembuangan pendudukpenduduk sipil

8) Penahanan pendudukpenduduk sipil dalam keadaan yang tidak manusiawi

9) Pemaksaaan penduduk sipil melakukan pekerjaan berkaitan dengan aktivitas militer musuh.

${ }^{23}$ Anis Widyawati, Op.Cit. hal. 72 menjelaskan tentang perbuatan-perbuatan apa saja yang termasuk ke dalam kejahatan perang dan dikutip di buku Anis Widyawati, Hukum Pidana

${ }^{24}$ Tholib Effendi, Op.Cit, hal 79. 
10) Perampasan kedaulatan selama pendudukan militer

11) Pemaksaan untuk dijadikan tentara dalam lingkungan pendudukan daerah yang diduduki.

12) Usaha menghapus kebangsaan penduduk daerah yang didudukinya.

13) Penjarahan

14) Pembeslahan harta milik (penyitaan)

15) Pemungutan pajak yang tidak sah atau yang tidak wajar atau penuntutanpenuntutan yang tidak wajar

16) Pemalsuan uang atau pengedaran (pengeluaran) uang palsu

17) Menjatuhkan hukumanhukumam kolektif

18) Dengan nekat merusak atau menghancurkan harta-harta milik

19) Dengan sengaja memborbardir tempattempat yang tanpa pertahanan

20) Dengan nekat merusak dan menghancurkan gedunggedung atau monumenmonumen keagamaan, karikatif, pendidikan atau yang bersejarah

21) Pengrusakan kapal-kapal penumpang atau kapalkapal niaga tanpa pemberitahuan lebih dahulu atau tanpa mengadakan upaya-upaya untuk menyelamatkan para penumpang dan awak kapal.
22) Pengrusakan kapal-kapal nelayan atau kapal-kapal penolong.

23) Pengeboman rumah-rumah sakit dengan sengaja

24) Penyerangan atau pengrusakan kapal-kapal hospital

25) Pelanggaran terhadap ketentuan-ketentuan lain menyangkut Palang Merah

26) Penggunaan gas beracun atau gas yang menyesakkan.

27) Penggunaan peluru-peluru peledak atau peluru-peluru penghancur

28) Perintah untuk tidak menampung seseorang

29) Perlakuan yang buruk terhadap orang-orang yang luka atau tawanan-tawanan perang.

30) Mempekerjakan tawanantawanan perang dengan cara yang tidak dibenarkan

31) Penyalahgunaan bendera putih

32) Meracuni sumber-sumber air.

33) Pembuatan pelaksanaan eksekusi atau pelaksanaan eksekusi yang kejam.

34) Perlakuan buruk terhadap penduduk yang diinternir atau tahanan-tahanan

35) Pembuatan pelaksanaan eksekusi atau pelaksanaan eksekusi yang kejam.

36) Tidak memberikan pertolongan atau merintangi pemberian pertolongan kepada korbankorban musibah kapal dilaut 
37) Dengan sengaja tidak mau memberikan obat-obatan kepada para penduduk.

38) Melakukan kegiatankegiatan permusuhan bertentangan dengan syarat-syarat genjatan senjata

39) Memberi infomasiinformasi, memberi kesempatan atau saranasarana kepada orang-orang lain untuk melakukan kegiatan permusuhan.

\section{Piagam London 08 Agustus} $1945^{26}$

Di dalam pasal 6 (b) dinyatakan bahwa yang dikategorikan kejahatan perang adalah pelanggaran undang-undang atau kebiasaan perang, dimana pelanggaran tersebut termasuk diantaranya tidak terbatas pada pembunuhan, perlakuan kejam atau pemindahan secara paksa untuk kerja paksa atau untuk tujuan lain bagi penduduk sipil yang wilayahnya diduduki, pembunuhan atau perlakuan kejam tahanan perang atau orang yang berada di laut, membunuh sandera, merampok barang milik umum atau pribadi, merusak kota atau desa, atau perusakan yang tidak dibenarkan oleh keperluan militer.
3. Pasal 5 (b) Charter of International Military Tribunal for The Far East (IMTFE) $^{27}$

Bahwa kejahatan perang diatur secara singakat sebagai berikut, "Conventional war crimes: namely violation of the laws or customs of war" yaitu pelanggaran terhadap hukum dan kebisaan perang.

\section{Pasal 8 Statuta Roma $1998^{28}$}

Pengaturan dalam Pasal 8 Statuta Roma 1998 adalah yang paling sistematis dan lengkap daripada pengaturanpengaturan sebelumnya. Bahwa menurut Statuta Roma kejahatan perang dibagi menjadi empat bentuk:

a. Grave breaches of the Geneva Convention of 12 Agustus 1949, namely, any of the following acts against persons and property protected under the provisions of the relevant Geneva Convention (Pelanggaran - pelanggaran berat terhadap Konvensi Jenewa 12 Agustus 1949 yang mencakup tindakantindakan yang ditujukan terhadap orang-orang atau benda-benda yang dilindungi oleh konvensikonvensi Jenewa) ${ }^{29}$

i. Wilful killing (pembunuhan secara sengaja)

\footnotetext{
${ }^{26}$ Lihat pasal 6 (b) Piagam London 08 Agustus 1945
}

\footnotetext{
${ }^{27}$ Lihat pasal 5 (b) Charter of International Military Tribunal for The far East (IMTFE)

${ }^{28}$ Baca Statuta Roma 1998 pasal 8

${ }^{29}$ Lihat Konvensi Jenewa 12 Agustus 1949
} 
ii. Torture or inhuman

treatment, including

biological experiments

(penyiksaan atau

perlakuan secara tidak

manusiawi, termasuk eksperimen biologis)

iii. Wilfully causing graet suffering, or serious injury to body or health (Secara sengaja menyebabkan penderitaan yang berat atau luka-luka serius terhadap tubuh atau kesehatan)

iv. Extensive destruction and appropriation of property, not justified by military and carrie out unlawfully and wantonly (penghancuran dan perampasan barangbarang secara luas, tanpa pertimbangan kepentingan militer dan dilakukan secara tidak sah dan sembarangan)

v. Compelling a prisioner of war or other protected person to serve in the forces of a hostile power (Memaksa tawanan perang atau penduduk sipil untuk melakukan tugas di dalam angkatan bersenjata pihak musuh)

vi. Wilfully depriving a prisioner of war or other protected person of the rights of fair ang regular trial (secara sengaja menyangkal hak untuk diadili secara jujur dalam pengadilan biasa yang dimiliki oleh tawanan perang atau penduduk sipil)

vii. Unlaw deportation or transfer of unlawful continement (deportasi, pemindahan atau penahanan penduduk sipil secara tidak sah)

viii. Taking of hostages (menyandera penduduk sipil)

b. Other serious violations of the laws and customs applicable in international armed conflict, within the established framework of international law, namely, any the following acts (Pelanggaran serius terhadap hukum dan kebiasaan dalam konflik bersenjata yang berada dibawah hukum internasional)

c. In the case of an armed conflict not of an international character, serious violations of article 3 common to the four Geneva Conventions of 12 August 1949, namely any of the following acts committed against person taking no active part in the hostilities, including members of armed forces who have laid down their arms and those placed hors de combat by sickness, wounds, detention or any other cause (dalam hal konflik bersenjata yang tidak bersifat internasional, pelanggaran serius pasal 3 yang terdapat di dalam empat Konvensi Jenewa tanggal 12 Agustus 1949, termasuk sebagai kejahatan 
perang, apabila perbuatan yang tersebut ditujukan terhadap seseorang yang tidak turut serta aktif di dalam permusuhan, termasuk anggota pasukan bersenjata yang telah meletakkan senjatanya dan mereka hors de combat ${ }^{30}$ karena sakit, luka-luka, penahanan atau kerena sebab lain.

d. Other serious violations of the laws and customs applicable in armed conflicts not an internasional character, within the established framework of international law, namely any of the following acts: (pelanggaran serius lainnya terhadap hukum dan kebiasaan internasional yang berlaku dalam konflik bersenjata bukan internasional, yang termasuk dalam hukum internsional)

Dari definisi yang diuraikan diatas maka kita dapat mengambil kesimpulan bahwa kejahatan perang (war crime) termasuk kedalam kejahatan

30 Hors de Combat adalah istilah dalam bahasa Perancis yang berarti diluar pertempuran, biasa dipergunakan dalam hukum internasional untuk memberikan status kepada prajurit yang tidak mampu menjalankan tugas militer. Protokol I Konvensi Jenewa 1949 dalam pasal 41 memberikan batasan tentang Hors de Combat ini, yaitu ketika seseorang tersebut: a) berada dalam pihak yang kurang baik, b) menunjukkan dengan jelas rasa untuk menyerah, c) dijadikan tidak sadar atau dilain pihak tidak mampu karena luka atau sakit dan oleh karena itu tidak mampu untuk melindungi diri sendiri. Dengan ketentuan, bahwa dia tidak akan melakukan permusuhan dan tidak akan melarikan diri. terhadap HAM berat (grave breaches) walaupun masih banyak difinisi-difinisi mengenai kejahatan perang karena sampai sekarang belum ada satu difinisi war crime yang dapat diterima oleh masyarakat internasional secara bulat. Beberapa pakar hanya dapat menyatakan bahwa war crime adalah kejahatan terhadap the law and customs of war yang bisa dikategorikan ke dalam Gravereaches.

\section{PENGADILAN HAK ASASI MANUSIA (HAM) BERAT}

Perwujudan penegakkan hukum pidana internasional dilakukan dengan membentuk pengadilan HAM Berat berdasarkan UndangUndang No.26 tahun 2000 tentang Pengadilan HAM Berat. Sebagaimana dinyatakan dalam penjelasan Undang-Undang ini, untuk melaksanakan amanat Ketetapan MPR RI No. XVII/MPR/1998 tentang Hak Asasi Manusia tersebut, telah dibentuk Undang-Undang No 39 tahun 1999 tentang HAM. Pembentukan Undang-Undang tersebut merupakan perwujudan tanggungjawab bangsa Indonesia sebagai anggota Perserikatan Bangsa-Bangsa (PBB).

Disamping hal itu, pembentukan Undang-Undang HAM juga mengandung suatu misi mengembang tanggungjawab moral dan hukum dalam menjunjung tinggi Deklarasi Universal Hak Asasi Manusia 
yang ditetapkan oleh $\mathrm{PBB}$, serta yang terdapat dalam berbagai instrumen hukum internasional lainnya yang mengatur hak asasi manusia yang telah disahkan atau diterima oleh Negara Republik Indonesia $^{31}$

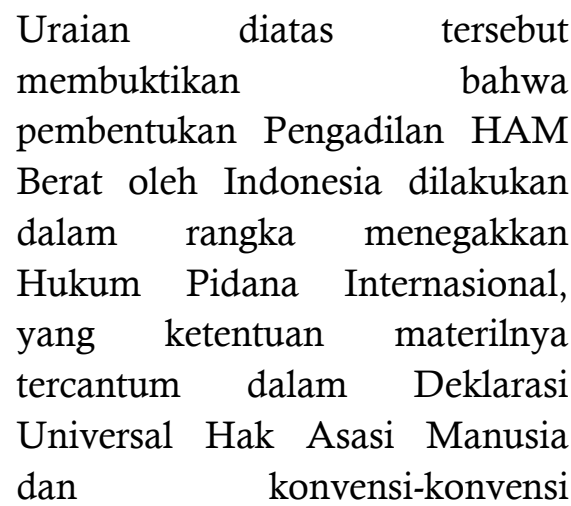
internasional tentang pelanggaran HAM berat sebagai derivasinya. Adapun isi Pembukaan UUD 1945 menyatakan kurang lebih bahwa untuk iku serta memelihara perdamaian dunia dan menjamin pelaksanaan hak asasi manusia serta memberikan perlindungan, kepastian, keadilan dan perasaan aman kepada perorangan ataupun masyarakat. ${ }^{32}$

Bagaimana pengaturan terhadap pelanggaran HAM berat? Masalah HAM pada umumnya, termasuk pelanggaran HAM berat menjadi tanggungjawab pemerintah dan tertuang dalam UUD 1945 dalam pasal Hak Asasi Manusia, mulai pasal 28, 28A, 28J, sampai 29. Juga dalam TAP MPR XVII/II/1998 tentang HAM, UU nomor 39/1999

${ }^{31}$ Oentoeng Wahjoe, Hukum Pidana Internasional Perkembangan Tindak Pidana Internasional dan Proses Penegakannya, Penerbit Erlangga, Jakarta, 2011, hal.157

${ }^{32} \mathrm{Ibid}$, hal 158. tentang HAM, UU nomor 26 tahun 2009 tentang Pengadilan HAM, Deklarasi Universal Human Rights 10 Desember 1948 serta Konvensi - Konvensi dan Perjanjian - Perjanjian Internasional tentang Hak-Hak Ekonomi, Sosial, Budaya dan Hak-Hak Sipil dan Politik. Ketentuan tersebut menjadi kewajiban hukum (constitusional duty) yang harus dilaksanakan pemerintah yang berkuasa (incumbant position) ${ }^{33}$

Di dalam Pasal 2 UU No 26 Tahun 2000 menetapkan bahwa Pengadilan HAM merupakan pengadilan khusus yang berada di lingkungan Peradilan Umum. Mengenai tempat kedudukan, dinyatakan dalam Pasal 3 berikut ini: ${ }^{34}$

1. Pengadilan HAM berkedudukan didaerah kabupaten atau daerah kota yang daerah hukumnya meliputi daerah hukum Pengadilan Negeri yang bersangkutan.

2. Untuk Daerah Khusus Ibukota Jakarta, Pengadilan HAM berkedudukan di setiap wilayah Pengadilan Negeri yang bersangkutan

Di dalam UU Nomor 26 Tahun 2000 tentang mengadilan HAM ini juga terdapat tiga mekanisme dalam menyelesaikan kasus-kasus pelanggaran HAM Berat;

${ }^{33}$ Masyur Effendi dan Taufani Sukmana Evandri, HAM Dalam Dimensi/Dinamika Yuridis, Sosial, Politik, Ghalia Indonesia, Bogor, 2007, hal 204.

${ }^{34}$ Lihat Pasal 2 dan 3 Undang-Undang Nomor 26

Tahun 2000 mengenai Pengadilan HAM 
Pertama, mekanisme pengadilan HAM ad hoc untuk pelanggaran HAM Berat masa lalu sebelum adanya UU No 26 Tahun 2000, artinya untuk kasus-kasus yang terjadi sebelum tahun 2000 akan di bentuk pengadilan HAM ad hoc. Kedua, pengadilan HAM yang sifatnya permanen terhadap kasus pelanggaran HAM berat setelah terbentuknya UU No 26 Tahun 2000. Ketiga, dibukakannya jalan mekanisme komisi kebenaran dan rekonsiliasi untuk menyelesaikan pelanggaran HAM Berat. ${ }^{35}$

Bahwa pengadilan HAM mempunyai sifat kekhususan tercermin dari kewenangannya yang terbatas hanya mengadili pelanggaran HAM berat dan berdasarkan kewenangan asas retroaktif yang dimilikinya serta tidak mengenal kadaluarsa untuk mengadili pelanggaran HAM berat. Secara rinci kekhususan yang dimaksud dalam pelanggaran HAM berat dapat dirumuskan sebagai berikut: ${ }^{36}$

1. Diperlukan penyelidik dengan membentuk tim ad hoc, penyidik ad hoc, penuntut umun ad hoc dan hakim ad hoc.

2. Diperlukan penegasan bahwa penyelidikan hanya dilakukan oleh Komisi Nasional Hak Asasi Manusia sedangkan penyidik tidak berwenang menerima laporan atau pengaduan sebagai mana diatur dalam
Kitab Undang-Undang Hukum Acara Pidana.

3. Diperlukan ketentuan mengenai tenggang waktu tertentu untuk melakukan penyidikan, penuntutan dan pemeriksaan di Pengadilan.

4. Diperlukan ketentuan mengenai perlindungan saksi dan korban

5. Diperlukan ketentuan mengenai penegasan tidak ada kadaluarsa bagi pelanggaran HAM berat.

6. Dapat diberlakuan asas retroaktif dalam rangka melindungi hak asasi manusia berdasarkan ketentuan Pasal 28 J UUD tahun 1945

\section{Yurisdiksi Pengadilan HAM Berat $^{37}$}

\section{Ratio Materiae}

Dalam pasal 4 UU No 26 Tahun 2000 dinyatakan bahwa Pengadilan HAM bertugas dan berwenang memeriksa dan memutus perkara Pelanggaran Hak Asasi Manusia Berat.

Pasal 7 UU No 26 Tahun 2000 bahwa Pelanggaran Hak Asasi Manusia Berat meliputi: ${ }^{38}$

1. Kejahatan Genosida

2. Kejahatan terhadap kemanusiaan

Kejahatan Genosida sebagaimana yang dimaksud dalam pasal 7 huruf a UU No. 26 Tahun 2000 adalah: setiap

${ }^{35}$ Bahder Johan Nasution, Op.Cit, hal 265

${ }^{37}$ Oentoeng Wahjoe, Op. Cit, hal 158-160

${ }^{36} \mathrm{Ibid}$, hal 266-267

${ }^{38}$ Lihat pasal 7 UU No.26 Tahun 2000 
perbuatan dengan maksud untuk menghancurkan atau memusnahkan seluruh atau sebagian kelompok bangsa, ras, etnis, agama, dengan cara membunuh anggota kelompok, mengakibatkan penderitaan fisik atau mental yang berat terhadap anggota-anggota kelompok, menciptakan kondisi kehidupan kelompok yang akan mengakibatkan kemusnahan secara fisik baik seluruh atau sebagiannya, memaksakan tindakan-tindakan yang bertujuan mencegah kelahiran di dalam kelompok, atau memindahkan secara paksa anak-anak dari kelompok tertentu ke kelompok lain. ${ }^{39}$

Pasal 9 UU No. 26 tahun 2000 merumuskan bahwa kejahatan terhadap kemanusiaan sebagaimana yang dimaksud dalam pasal 7 huruf $b$ adalah salah satu perbuatan yang dilakukan sebagai bagian dari serangan yang meluas atau sistematis yang dimaksud menyerang secara langsung terhadap penduduk sipil berupa: ${ }^{40}$

1. Pembunuhan

2. Pemusnahan

3. Perbudakan

4. Pengusiran atau pemindahan penduduk secara paksa

5. Perampasan kemerdekaan atau perampasan kebebasan fisik lain secara sewenangwenang yang melanggar

${ }^{39}$ Lihat pasal 7 huruf a UU No.26 tahun 2000 yang menjelaskan tentang ruang lingkup GENOSIDA.

${ }^{40}$ Lihat pasal 9 UU No 26 Tahun 2000 tentang Pengadilan HAM yang merumuskan ruang lingkup Kejahatan Terhadap Kemuanusiaan. (asas-asas) ketentuan pokok hukum internasional.

6. Penyiksaan

7. Perkosaan, perbudakan seksual, pelacuran secara paksa, pemaksaan kehamilan, pemandulan atau sterilisasi secara paksa atau bentuk-bentuk kekerasan seksual lain yang setara,

8. Penganiayaan terhadap suatu kelompok tertentu atau perkumpulan yang didasari persamaan paham politik, ras, kebangsaan, etnis, budaya, agama, hal yang dilarang menurut hukum internasional.

9. Penghilangan orang secara paksa

10. Kejahatan apartheid

\section{Ratio Personae}

Pengadilan HAM hanya berwenang mengadili orang perorangan, kelompok orang, baik sipil, militer maupun polisi yang bertanggungjawab secara indivudual. Pasal 5 UU No.26 Tahun 2000 menyatakan $^{41}$ bahwa Pengadilan HAM berwenang juga memeriksa dan memutuskan perkara pelanggaran Hak Asasi Manusia Berat yang dilakukan di luar batas teritorial wilayah Negara Kesatuan Republik Indonesia. Adapun pasal $6 \mathrm{UU}$ No 26 Tahun $2000^{42}$ menetapkan bahwa Pengadilan HAM tidak berwenang memeriksa dan memutuskan perkara pelanggaran hak asasi manusia berat yang

${ }^{41}$ Lihat pasal 5 UU No. 26 Tahun 2000

${ }^{42}$ Lihat pasal 6 UU No.26 Tahun 2000 
dilakukan oleh seseorang yang berumur dibawah delapan belas tahun pada saat kejahatan dilakukan.

\section{Rasio Temporis}

Tentang waktu berlaku Pengadilan HAM ini tidak diatur secara jelas, namun bila mencermati ketentuan BAB VIII tentang Pengadilan HAM Ad Hoc, sebagaimana yang dinyatakan Pasal 43 ayat (1) UU No.26 Tahun $2000^{43}$ bahwa: "Pelanggaran Hak Asasi Manusi Berat yang terjadi sebelum diundangkan Undang-Undang ini, diperiksa dan di putus oleh Pengadilan HAM Ad Hoc", Pengadilan HAM Berat hanya berwenang mengadili untuk peristiwa pidana internasional berupa pelanggaran HAM Berat, yang terjadi setelah UndangUndang ini di berlaku. Dengan demikian, Pengadilan HAM berdasarkan ketentuan UndangUndang No. 26 tahun 2000, tidak bersifat retroaktif.

\section{Ratio Loci}

Pengadilan HAM mempunyai yurisdiksi terhadap peristiwa pelanggaran berat, baik di dalam maupun di luar wilayah Republik Indonesia. Di dalam Pasal 5 UU No 26 Tahun 2000 disebutkan "Pengadilan HAM berwenang juga memeriksa dan memutus perkara pelanggaran Hak Asasi Manusia yang berat yang dilakukan di luar batar territorial
Negara Republik Indonesia oleh warga negara Indonesia" 44 Ketentuan dalam pasal ini hanya dimaksudkan untuk melindungi warga negara Indonesia yang melakukan pelanggaran Hak Asasi Manusia yang berat yang dilakukan di luar batas territorial, dalam arti tetap di hukum sesuai dengan Undang-Undang tentang Pengadilan Hak Asasi Manusia ini.

Keberadaan Pengadilan HAM Ad Hoc Jakarta Pusat yang memeriksa dan mengadili perkara HAM Berat dibentuk berdasarkan Keppres No. 96 tahun 2001, tanggal 1 Agustus 2001, tentang perubahn atas Keppres No.53 tahun 2001 tentang pembentukan Pengadilan HAM Ad Hoc. Pembentukan Pengadilan HAM Ad Hoc ini diatur secara jelas dalam pasal 43 UU No. 26 Tahun 2000 yang menjadi konsideran Keppres No 96 tahin 2001, dimana Pasal 43 UU No 26 Tahun 2000 tersebut menyatakan: "Pemeriksaan di Pengadilan HAM Ad Hoc dan upaya hukumnya dilakukan sesuai dengan ketentuan UndangUndang". Dengan demikian Keppres tersebut tidak boleh dilaksanakan secara bertentangan dengan UU No. 26 Tahun 2000 yang berlaku dan secara hierarkis lebih tinggi daripada Keppres. Berdasarkan ketentuan hukum pasal 45 ayat1 dan 2 BAB IX Republik Indonesia No. 26 Tahun 2000, mengenai

${ }^{43}$ Baca Pasal 43 ayat 1 UU No.26 Tahun 2000

${ }^{44}$ Pasal 5 UU No.26 Tahun 2000 
Pengadilan HAM dinyatakan sebagai berikut: ${ }^{45}$

1. Untuk pertama kalinya pada saat undang-undang ini mulai berlaku pengadilan sebagaimana disebut dalam Pasal 4 dibentuk di Jakarta Pusat, Surabaya, Medan dan Makasar.

2. Daerah Hukum Pengadilan HAM sebagaimana yang dimaksud dalam ayat (1) berada pada pengadilan negeri di:

a. Jakarta Pusat yang meliputi wilayah daerah khusus Ibukota Jakarta, Jawa Barat, Banten, Sumatera Selatan dan Kalimantan Tengah.

b. Surabaya yang meliputi Jawa Timur, Jawa Tengah, Daerah Istimewa Yogyakarta, Bali, Kalimantan Selatan, Kalimantan Timur, Nusa Tenggara Barat dan Nusa Tenggara Timur.

c. Makasar yang meliputi Sulawesi Selatan, Sulawesi Tenggara, Sulawesi Tengah, Sulawesi Utara, Maluku Utara dan Papua.

d. Medan yang meliputi Propinsi Sumatera Utara, Daerah Istimewa Aceh, Riau, Jambi dan Sumatera Barat.

${ }^{45}$ Oentoeng Wahjoe, $O p$, Cit, hal 161. Dan lihat juga Keppres No 96 tahun 2001, Keppres No. 53 Tahun 2001 tentang Pembentukan Pengadilan HAM ad Hoc. Kemudian lihat Pasal 43 , pasal 45 ayat (1) dan (2) BAB IX UU Republik Indonesia No 26 Tahun 2000 tentang Pengadilan HAM

\section{PENUTUP}

Dalam tulisan ini sebagai penutup menulis mencoba untuk menjawab permasalahan yang diangkat dan tentu merupakan juga kesimpulan dari tulisan yang penulis bahas.

Selanjutnya yang dimaksud dengan pelanggaran-pelanggaran HAM berat (grave breaches) adalah tindakantindakan yang dikategorikan sebagai pelanggaran-pelanggaran berat dalam Konvensi Jenewa 1949 dan Protokol Tambahan 1977 yang berlaku dalam sengketa/konflik bersenjatan Internasional. Adapun pelanggaranpelanggaran berat (grave breaches) yang dimaksud lebih diuraikan lagi di pasal 50 Konvensi Genewa 1949 dimana dijelaskan bahwa grave breaches yaitu pelanggaran - pelanggaran yang meliputi perbuatan-perbuatan berikut, apabila dilakukan terhadap orang atau milik yang dilindungi oleh Konvensi: pembunuhan disengaja, penganiayaan atau perlakuan yang tidak berperikemanusiaan, termasuk percobaan - percobaan biologis, menyebabkan dengan sengaja penderitaan besar atau luka berat atas badan atau kesehatan, serta penghancuran yang luas dan tindakan perampasan atas harta benda yang tidak dibenarkan oleh kepentingan militer.

Kejahatan Genosida adalah: setiap perbuatan dengan maksud untuk menghancurkan atau memusnahkan seluruh atau sebagian kelompok bangsa, ras, etnis, agama, dengan cara membunuh anggota kelompok, mengakibatkan penderitaan fisik atau mental yang berat terhadap anggotaanggoat kelompok, menciptakan kondisi kehidupan kelompok yang 
akan mengakibatkan kemusnahan secara fisik baik seluruh atau sebagiannya, memaksakan tindakantindakan yang bertujuan mencegah kelahiran di dalam kelompok, atau memindahkan secara paksa anak-anak dari kelompok tertentu ke kelompok lain.

Kejahatan perang (war crime) termasuk kedalam kejahatan terhadap HAM berat (grave breaches) walaupun masih banyak difinisi-difinisi mengenai kejahatan perang karena sampai sekarang belum ada satu difinisi war crime yang dapat diterima oleh masyarakat internasional secara bulat. Beberapa pakar hanya dapat menyatakan bahwa war crime adalah kejahatan terhadap the law and customs of war yang bisa dikategorikan ke dalam Grave breaches.

Adapun persaman Genocide dan War Crime adalah: baik Genocide maupun War Crime dua-duanya digolongkan pada Grave Breaches (Pelangggaran Terhadap Hak Asasi Manusia Berat). Dan pelanggaran- pelanggaran Hak Asasi Berat Manusia tersebut baik itu Genocide maupun War Crime dapat kita jumpai pada pasal 50 Konvensi Jenewa 1942. Kedua pelanggaran Hak Asasi Manusia Berat ini biasanya dilakukan secara tersrtuktur, sistematis dan massif. Perbedaannya adalah bahwa Genocide bisa saja terjadi disaat tidak ada peperangan tetapi War Cime pasti terjadi pada saat peperangan dimana jelas-jelas melanggar Hukum Perang dan Kebiasaan Perang.

\section{DAFTAR PUSTAKA}

Effendi, A. Mansyur dan Evandri, Taufani Sukmana, HAM Dalam Dimensi/Dinamika Yuridis, Sosial, Politik, Ghalia Indonesia, Bogor, 2007.

Effendi, Tolib, Hukum Pidana Internasional, Pustaka Yustisia, Yogyakarta, 2014

Hiariej, Eddy O.S, Pengantar Hukum Pidana Internasional, Erlangga, Jakarta, 2009

Nasution, Bahder Johan, Negara Hukum Dan Hak Asasi Manusia, Mandar Maju, Bandung, 2012.

Wahjoe, Oentoeng, Hukum Pidana Internasional Perkembangan Tindak Pidana Internasional Dan Proses Penegakannya, Erlangga, Jakarta, 2011.

Widyawati, Anis, Hukum Pidana Internasional, Sinar Grafika, Jakarta, 2014

TEMPO, 8-14 Juni 2015

Undang-Undang Nomor 39 Tahun 1999 Tentang HAM

Undang-Undang Nomor 26 Tahun 2000 Tentang Pengadilan HAM

Keppres No. 53 Tahun 2001 Tentang Pembentukan Pengadilan HAM Ad Hoc

Keppres No.96 tahun 2001 Tentang Perubahan atas Keppres No.53 Tahun 2001

Statuta Roma Tahun 1998

Konvensi Jenewa Tahun 1949

Piagam London 08 Agustus 1945

Charter of International Military Tribunal for The Far East (IMTFE)

Deklarasi Universal Hak Asasi Manusia PBB 1948 